\title{
SMARTPHONE USE IN LEARNING AS PERCEIVED BY UNIVERSITY UNDERGRADUATES: BENEFITS AND BARRIERS
}

Thouqan Saleem Yakoub Masadeh ${ }^{*}$ 伲 (iD)

${ }^{* 1}$ Department of Curriculum and Instruction, Najran University, KSA, Saudi Arabia

DOI: https://doi.org/10.29121/granthaalayah.v9.i3.2021.3764

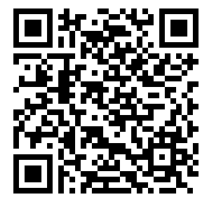

Article Type: Research Article

Article Citation: Thouqan Saleem

Yakoub Masadeh. (2021).

SMARTPHONE USE IN LEARNING

AS PERCEIVED BY UNIVERSITY

UNDERGRADUATES: BENEFITS

AND BARRIERS. International

Journal of Research -

GRANTHAALAYAH, 9(3), 56-65.

https://doi.org/10.29121/granthaa

layah.v9.i3.2021.3764

Received Date: 10 February 2021

Accepted Date: 22 March 2021

Keywords:

Smartphone's Ease of Use

Smartphone's Usefulness

Barriers of Smartphone Use

Effects of Smartphone Use

University Undergraduates

\begin{abstract}
Smartphones are attractive tools for the majority of young people particularly university undergraduates and integrating them in learning is something valuable. Nevertheless, they might do harm to their achievement if the use barriers and bad effects are not identified. Motivated by this idea, the present study was undertaken. Participants were (42) university undergraduates at the departments of mathematics and English language at Najran University in the first semester of the academic year $2020 / 2021$. Findings showed that students were agreeable to smartphone perceived usefulness, ease of use, and barriers. However, their responses to the effects of smartphone use were not clear. The majority of them were neutral, i.e. could not decide whether smartphones affect their learning or not. In light of these results, the study concluded that smartphone technology integration in learning is very crucial but when barriers and bad effects are clear to both teachers and students.
\end{abstract}

\section{INTRODUCTION}

None of us ignores the fact that smartphones have become essential parts of today's human being life. Their roles are becoming more and more important, particularly these days, which are characterized by everywhere lockdown because of Coronavirus Pandemic. Interactions between people have become digital where no meetings, no festivals, no condolences, no face-to-face education can be held or organized. Therefore, smartphones applications are to be used in a wider range of situations among which is the cyber learning. Smartphones are defined as; those cell phones that allow their users to do more than making phone calls and sending text messages. They can browse the Internet and run software programs like a computer. Their touch screens make it easier for users to interact with them (Computer Hope website, 2012). In addition, "A smartphone combines the cellphone with email and Web, music and movie player, camera, camcorder, GPS navigation, voice recorder, alarm clock, flashlight, photo album, address book and a lot more. Smartphone is the user's personal assistant that can deliver information and answer questions about almost everything (PC Magazine Encyclopedia, 2021). Thus, the enhancement in the varied functions of the smartphone has created exceptional and unlimited opportunities for both teachers and learners.

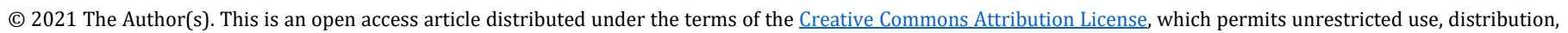
and reproduction in any medium, provided the original author and source are credited. 
Hence, it has been of a vital supportive role that supports and enriches the educational process of both teachers and learners (Kyobe \& Van Belle, 2018). With the increase in the number of students of today's generation who own mobile devices and smartphones, utilization of these devices in teaching and learning has been essential (Brown, Ferguson, Grant, Jones, Sweeney, \& Tamim, 2015)

In the past, and particularly near past, mobile phones were not seen as an integral part of students' lives, but the introduction of smartphones changed the attitudes of teachers and learners toward them (White \& Mills, 2014). Self-directed learning and study have been occurring because of students' use of their smartphones and the responsibility of learning has been transferred from the teacher to the student (Kondo, Ishikawa, Smith, Sakamoto, Shimomura, Wada, 2012). Apart from the fact that smartphone technologies are mostly used for communication and social media purposes, they are nowadays used incontrovertibly for certain educational purposes (Wisnuwardana, 2019). Smartphones have been replacing computers, and an email application is mostly used. The smartphone is being utilized as a means for knowledge downloading, uploading, and sharing (Al Fawareh \& Jusoh, 2017). Students nowadays can run effectively their study time. They can grasp updated e-books and online prerequisite materials using different kinds of software that are popular in smartphones (Cochrane \& Bateman, 2010) making learning more flexible, enjoyable and time and place efficient (Masadeh \& Elfeky, 2016).

In Saudi Arabia, as well as other countries, most undergraduates own smartphones and use them for different purposes. Blended learning in Saudi universities mainly in Najran University has been common for some years and students either did their duties inside classrooms or via an educational system named "Blackboard" (Masadeh, 2021). In line with Covid-19 pandemic, face-to face education has been stopped nearly all over the world. Therefore, Saudi undergraduates have to move to online learning via the use of Blackboard system and they have to join online lectures and electronically submit their assignments, read course-related announcement, and more importantly sit for exams. Thus, the availability of smartphones with users, their strong batteries, touch screen, and the millions of the downloadable applications have made it an indispensable device in the area of mobile learning (Godwin-Jones, 2011).

Hence, the present study aims to investigate the ease and usefulness of smartphone use in learning. Moreover, it seeks to determine the most important benefits and barriers of smartphone use from the viewpoint of undergraduates at Najran University. Particularly, it aims to answer these questions:

1) To what extent is the smartphone use in learning easy from the viewpoint of undergraduates?

2) What are the most important benefits of smartphone use in learning from the viewpoint of undergraduates?

3) What are the most important effects of smartphone use on the learning activities from the viewpoint of undergraduates?

4) What are the most important barriers that inhibit the effective smartphone use as a learning tool from the viewpoint of undergraduates?

\section{RELATED LITERATURE}

\subsection{BENEFITS OF SMARTPHONE USE IN LEARNING}

The accelerated enhancement in smartphones and consequently the fast growth of the number of their users in the present era have caused these devices to play an essential role in learners' lives and learning (Esmaeili, Eydgahi, \& Amanov, 2015). In a study by Wisnuwardana (2019), it was found that students were considerably enthusiastic for using apps to support learning because of their substantial potentials that can be enhanced for learning through systematic and purposeful activities properly designed for learning-related activities. The results of Naz, Rasheed, \& Rasheed (2019), on the other hand, showed that students were willing and motivated to adapt their smartphones for learning English because of the positive role they play in helping them to learn. In addition, students' attitudes toward the role of smartphones in learning English were positive. Nikolopoulou (2019) identified different perceived benefits of smartphone use such as their involvement, motivation and active participation, the easy access to information, students' familiarity with technology in addition to the fact that smartphone utilization made the lesson interactive and enjoyable. Meanwhile, the study of Iqbal \& Bhatti (2020) revealed that smartphones were an effective medium for off-campus learning and communication with peers and students. Complex topics were explained easily to students as audio-visual content can be available over the Internet and can be shared easily. However, the majority of the respondents were skeptical about using smartphones for educational purposes as they 
considered them a source of distraction, wastage of time, technostress, and emotional detachment. Moreover, they reported that small size of both the screen and keyboard are important limiting factors undermining the effective use of smartphones in education. Lack of training and support, lack of technical knowledge and background, excessive workload and lack of incentives for using technology in education were believed as major barriers in adoption of smartphones in higher learning landscape.

Moreover, Alzougool \& Almansour (2017) concluded that university undergraduates usually use their smartphones to check the exams' schedule, class timetable, and grades and to login to the university portal, use blackboard (LMS) to participate in class learning groups, download class material, register courses, read tutors' announcements, and pay fees. Cochrane (2010) argues that students use their smartphones in various educational activities. They use them to access course content, acquire information related to their performance, participate in course group discussions, and share information. Mohammadi, Sarvestani \& Nouroozi (2020) claim that using the mobile phone, as a teaching aid, enhances the student's participation, management and planning of the teaching process.

\subsection{BARRIERS INHIBITING THE EFFECTIVE SMARTPHONE USE IN ONLINE LEARNING}

With regard to the barriers, Nikolopoulou (2019) mentioned that the lack of equipment and the current legislation regarding mobile technology use in school settings were the most important factors inhibiting the effective utilization of smartphones in learning. Factors like students' abusive behavior, control, noise, and distraction were bad results of smartphones for online lessons. Iqbal \& Bhatti (2020) stressed these facts claiming that smartphones use causes students' distraction, technostress and emotional detachment; and wastes their time. Kadry \& Roufayel (2017) mention the frustration caused by students to teachers while using their smartphones inside class by texting, tweeting, and snap chatting that produce an incredible distraction and make the teaching environment very complex. Rung, Warnke, \& Mattheos (2014) state that smartphones open opportunities for innovative ways to learn and teach. Their use encourage instructors to search for new teaching methods to see if that learning content is accessible, and if interaction is possible through smartphones regardless of teaching staff intervention.

Mohammadi, Sarvestani \& Nouroozi (2020) talk about bad effects of smartphone use in learning like for example student's attempts to search for inappropriate content on the internet, cheat in the exams, and violate the privacy of instructor and colleagues. Whilst the small screen, decrease in learning concentration, inequality among students regarding the ownership and availability of smartphone services are also main barriers but of less impact. Moreover, Real, DeBlasio, Rounce, Henize, Beck, \& Klein (2018) argue that the main difficulties of smartphone use in learning are related to Wi-Fi access, phone memory availability, phone data existence, and discomfort with technology. Masadeh (2021) and Yeik (2018) say that the prevalence of cyberloafing behaviors during lecture times might be severe barriers for the effective use of smartphones in learning.

In conclusion, it can be claimed that nothing is complete. Everything has both merits and demerits. Literature and scientific research concerning the effect and barriers of smartphone in learning have not proved its efficacy or failure. Therefore, investigating the viewpoints of students as stakeholders would reveal more and more about using smartphones as learning tools. Nevertheless, their perceptions might not convince other partners like educationalists, instructors and parents to encourage the adoption of smartphone use in education as a learning tool.

\section{METHOD}

\subsection{STUDY DESIGN}

The descriptive research design was used in the present study as was described by (Ary, Jacobs, Razavieh, \& Sorensen, 2006) to collect data from participants.

\subsection{PARTICIPANTS}

Participants were (42) students selected via the convenience sampling technique. They were all enrolled in two courses, namely Practicum course for mathematics students $(\mathrm{N}=19)$ and Practicum course for English language 
students $(\mathrm{N}=23)$. Both courses were offered by the department of curriculum and instruction at Najran University in the first semester of the academic year 2020/2021. Through WhatsApp messages, they were informed about the aim of the study and requested to take part in the survey. As soon as they agreed, the questionnaire link was send to them and they electronically completed it.

\subsection{INSTRUMENT}

The questionnaire is probably the most appropriate means to collect original data from respondents. A fiveaspect questionnaire that was used by Adjei (2019) was adopted in the present study, with some slight modifications, to obtain data from students at Najran University in accordance with their smartphones use in learning. The first aspect focused on participants' demographic information. The second aspect was concerned with students' perceptions about the ease of smartphone use (6 items). The third aspect was interested in surveying students' perceptions about the usefulness of smartphone use (13 items). The fourth aspect concentrated on determining the effects of smartphone use on students' learning activities (6 items). The last one attempted to allocate the factors that inhibit the use of smartphones as learning tools (7 items). Using Likert's Scale, five responses were attached to each statement namely strongly disagree $=1$, disagree $=2$, can not decide $=3$, agree $=4$, and strongly disagree $=5$. Mean scores ranging between 1.00-1.80 expressed students' strong disagreement, 181-2.60 expressed students' disagreement, 2.61-3.40 expressed students' inability to decide, 3.41-4.20 expressed students' agreement, and 4.215.00 expressed students' strong agreement.

\section{RESULTS}

\subsection{PERCEIVED EASE OF SMARTPHONE USE IN LEARNING}

In order to understand students' viewpoint about the ease of smartphone use as a learning tool, they were asked to rate their agreement degree to items in the second aspect of the questionnaire. Mean scores and standard deviations of their responses are shown in table 1.

Table 1: Students' perceptions of the perceived ease of smartphone use in learning

\begin{tabular}{|c|c|c|c|c|c|}
\hline $\mathrm{N}$ & Perceived Ease of smartphone use in learning & $\mathrm{M}$ & $\mathrm{SD}$ & $\begin{array}{c}\text { Agreement } \\
\text { level }\end{array}$ & Rank \\
\hline & I find it easy to use my smartphone for reading. & 4.14 & 0.68 & Agree & $1_{\text {st }}$ \\
\hline & The interface of my smartphone is user friendly and flexible to use. & 4.10 & 0.96 & Agree & $2_{\text {nd }}$ \\
\hline & $\begin{array}{c}\text { My interaction with my smartphone for learning is clear and } \\
\text { understandable. }\end{array}$ & 4.04 & 0.94 & Agree & $3_{\text {rd }}$ \\
\hline $\begin{array}{c}\text { I find it easy to use the smartphone for retrieval course material from } \\
\text { blackboard system. }\end{array}$ & 3.90 & 1.10 & Agree & $4_{\text {th }}$ \\
\hline $\begin{array}{c}\text { I do not encounter technical problems when using my smartphone for } \\
\text { learning }\end{array}$ & 3.48 & 1.15 & Agree & $5_{\text {th }}$ \\
\hline & $\begin{array}{c}\text { Using my smartphone for learning does not require any special } \\
\text { computer literacy skills in order to use. }\end{array}$ & 3.12 & 1.02 & Neutral & $6_{\text {th }}$ \\
\hline & Overall mean & 3.80 & & Agree & \\
\hline
\end{tabular}

Table 1 shows items used to measure the level of students' perceived ease of smartphone use in learning. The overall mean score of participants' responses to this aspect was $(M=3.80)$ showing their agreement, but not strong agreement, on the fact that smartphone use as a learning tool was easy. That is, students were agreeable that smartphones are easy to use in learning. The item "I find it easy to use my smartphone for reading" was at the top of the list and got the highest agreement level $(M=4.14)$. The item "The interface of my smartphone is user friendly and flexible to use" $(M=4.10)$ was in the second place while the item "My interaction with my smartphone for learning is clear and understandable" (M=4.04) was in third place. The item that students could not make up their minds and decide whether smartphone use makes learning easy or not was "Using my smartphone for learning does not require any special computer literacy skills in order to use" $\mathrm{M}=3.12$ ). 


\subsection{PERCEIVED USEFULNESS OF SMARTPHONE USE IN LEARNING}

Investigating participant students' viewpoints in accordance to the perceived usefulness of smartphones as learning tools, participant students were to reply to all items involved in the third aspect of the administered questionnaire. Mean scores and standard deviations of their agreement levels were calculated. Table 2 presents the results.

Table 2: Students' perceptions of the perceived usefulness of smartphone use in learning

\begin{tabular}{|c|c|c|c|c|c|}
\hline $\mathrm{N}$ & Perceived usefulness of smartphone use in learning & M & SD & $\begin{array}{l}\text { Agreement } \\
\text { level }\end{array}$ & Rank \\
\hline & I can easily access my e-mail using my smartphone. & 4.45 & 0.55 & S. agree & $1_{\mathrm{st}}$ \\
\hline & $\begin{array}{c}\text { My smartphone helps me in sharing lecture materials among } \\
\text { colleagues. }\end{array}$ & 4.21 & 0.81 & S. agree & 2 nd \\
\hline & My smartphone enables me to participate in online group discussion & 4.19 & 0.74 & Agree & $3_{\mathrm{rd}}$ \\
\hline & My smartphone helps me to store all my lecture materials & 4.10 & 0.98 & Agree & $4_{\text {th }}$ \\
\hline & $\begin{array}{l}\text { My smartphone enables me to schedule my lecture activities with } \\
\text { reminder }\end{array}$ & 4.09 & 073 & Agree & $5_{\text {th }}$ \\
\hline & My smartphone enables me to record lectures delivered by my tutors & 4.05 & 0.76 & Agree & $6_{\text {th }}$ \\
\hline & $\begin{array}{c}\text { My smartphone enables me to easily receive notification when } \\
\text { announcement is posted on the Sakai LMS }\end{array}$ & 4.02 & 0.98 & Agree & $7_{\text {th }}$ \\
\hline & $\begin{array}{l}\text { My smartphone enables me to use social media platform for class } \\
\text { activities }\end{array}$ & 4.00 & 0.83 & Agree & 8 th \\
\hline & $\begin{array}{l}\text { My smartphone enables me to take a snapshot of illustration which } \\
\text { cannot be memorized at instance for later date }\end{array}$ & 3.79 & 0.92 & Agree & $9_{\text {th }}$ \\
\hline & $\begin{array}{c}\text { Smartphone enables me to easily and effectively use the Sakai LMS for } \\
\text { learning }\end{array}$ & 3.79 & 0.95 & Agree & $10_{\text {th }}$ \\
\hline & $\begin{array}{l}\text { Using my smartphone for learning has enabled me to gain extra skills } \\
\text { and experiences outside the classroom }\end{array}$ & 3.74 & 1.13 & Agree & $11_{\text {th }}$ \\
\hline & $\begin{array}{l}\text { My smartphone enables me to take quizzes and Interim Assessment } \\
\text { (IA) anywhere and anytime }\end{array}$ & 3.36 & 1.23 & Neutral & $12_{\text {th }}$ \\
\hline & My smartphone has saved me from buying personal laptop for studies. & 2.93 & 1.44 & Neutral & $13_{\text {th }}$ \\
\hline & Average mean & 3.90 & & Agree & \\
\hline
\end{tabular}

Table 2 shows the items used to measure the level of students' perceived usefulness of smartphone use in learning. The overall mean score of participants' responses to this aspect was $(M=3.90)$ indicating an agreement, but not strong agreement level on the fact that smartphone use was useful for their learning process. That is, students were agreeable on the fact that smartphones are useful in learning. The item "I can easily access my e-mail using my smartphone" was at the top of the list and got strong agreement level $(M=4.45)$. The item "My smartphone helps me in sharing lecture materials among colleagues" (M=4.21) was in the second place and had a strong agreement level, too. However, students were unable to decide whether smartphones were enough for learning and so students were not in an urgent need for buying PCs or laptops" $(\mathrm{M}=2.90)$. They also were unable to determine the usefulness level of smartphones in quizzes and Interim Assessment anywhere and anytime $(M=3.36)$. With regard to other items, mean scores prove that students agreed but not strongly agreed on the smartphone usefulness in learning. Mean scores ranged between $(\mathrm{M}=4.19-\mathrm{M}=3.74)$.

\subsection{PERCEIVED EFFECTS OF SMARTPHONE USE ON STUDENTS' LEARNING ACTIVITIES}

Distinction of the main factors affecting the smartphone use in learning activities needed analysis of respondents' perceptions about the items in the fourth aspect. Mean scores and standard deviations of participants' perceptions are presented in table 3 . 
Table 3: Students' perceptions of the perceived effects of smartphone use in learning

\begin{tabular}{|c|c|c|c|c|c|}
\hline $\mathrm{N}$ & $\begin{array}{c}\text { Perceived Effects of smartphone use on students' learning activities } \\
\text { Using the smartphone for learning consumes a lot of data bundle which } \\
\text { increase my expenditure }\end{array}$ & 3.38 & 1.34 & $\begin{array}{c}\text { Agreement } \\
\text { level }\end{array}$ & Rank \\
\hline $\begin{array}{c}\text { The smartphone use in learning creates an isolation or a feeling of being } \\
\text { out of the-loop for both instructors }\end{array}$ & 3.14 & 1.22 & Neutral & $2_{\text {st }}$ \\
\hline $\begin{array}{c}\text { The smartphone can potentially increase multitasking and task } \\
\text { switching during academic activities leading to decrease in academic } \\
\text { performance }\end{array}$ & 3.07 & 1.00 & Neutral & $3_{\text {rd }}$ \\
\hline & $\begin{array}{c}\text { SD } \\
\text { The smartphone takes more of my attention from studies } \\
\text { Sometimes I am not able to pay attention in class because of my } \\
\text { smartphone }\end{array}$ & 2.81 & 1.17 & Neutral & $4_{\text {th }}$ \\
\hline $\begin{array}{c}\text { I always use my smartphone more for playing games and accessing } \\
\text { social media platforms instead of using it for learning }\end{array}$ & 2.64 & 1.16 & Neutral & $5_{\text {th }}$ \\
\hline Average mean & 2.96 & & Neutral & $6_{\text {th }}$ \\
\hline
\end{tabular}

Table 3 presents the items used to measure the level of perceived effects on smartphone use as a learning tool. Mean scores of respondents' choices indicate high degree of uncertainty in accordance with effects of smartphone use on students' learning activities $(M=2.96)$. The only effect upon which students agreed was the fact that smartphone use in learning consumes a lot of students' data bundles and consequently increases their expenditures $(\mathrm{M}=3.38)$. In other words, students were not sure whether smartphone use creates an isolation or a feeling of being out of the-loop, increases multitasking and task switching during academic activities, which decreases academic performance, takes more of their attention from studies, and encourages them to play games and access social media platforms instead of using it for learning.

\subsection{PERCEIVED BARRIERS FOR THE USE OF SMARTPHONE AS A LEARNING TOOL}

Addressing the barriers facing the effective use of smartphones as a learning tool means requesting students to determine their viewpoints regarding the items administered in the fifth section. Mean scores and standard deviations of their agreement levels are presented in table 4.

Table 4: Students' perceptions of the perceived barriers of smartphone use in learning

\begin{tabular}{|c|c|c|c|c|c|}
\hline $\mathrm{N}$ & Perceived barriers of smartphone use as a learning tool & M & SD & $\begin{array}{l}\text { Agreement } \\
\quad \text { level }\end{array}$ & Rank \\
\hline & $\begin{array}{l}\text { Without internet bundle or Wi-Fi connection, I cannot access course } \\
\text { information online }\end{array}$ & 4.21 & 0.90 & S. agree & $1_{\text {st }}$ \\
\hline & Unstable internet connectivity & 4.10 & 0.88 & Agree & 2 nd \\
\hline & Intruding calls may come in during learning & 3.92 & 1.20 & Agree & 3 rd \\
\hline & The phone can freeze during important learning moments & 3.69 & 1.12 & Agree & $4_{\text {th }}$ \\
\hline & $\begin{array}{l}\text { File/formats of contents sometimes do not support Smartphone } \\
\text { browsing }\end{array}$ & 3.57 & 1.04 & Agree & 5 th \\
\hline & $\begin{array}{l}\text { The screen and key sizes make Smartphone uncomfortable for } \\
\text { learning }\end{array}$ & 3.52 & 1.21 & Agree & $6_{\text {th }}$ \\
\hline & Difficult to get access to use smartphone during constant power cut & 3.40 & 1.27 & Neutral & $7_{\text {th }}$ \\
\hline & Average mean & 3.77 & & Agree & \\
\hline
\end{tabular}

Table 4 presents items used to measure the level of perceived effects on smartphone use as a learning tool. Mean scores of respondents' choices indicate logical perceived compatibility among respondents toward the perceived barriers of smartphone use in learning $(M=3.77)$. That is, students were agreeable on the fact that there are some hindrances facing using smartphones effectively in learning. The most important barrier, upon which students strongly agreed, was the idea that without internet bundle or Wi-Fi connection, accessing course information online 
becomes difficult $(M=4.21)$. Difficulty to use smartphones during constant power cut was not seen a real barrier to smartphone use though students were unable to decide $(M=3.40)$. Other items like, unstable internet connectivity, intruding calls during lecture time, phone freezing during important learning moments, file formats that do not support browsing, the small screen and keyboard were real barriers for the effective use of smartphones. Mean scores were ranging from $(\mathrm{M}=4.10-\mathrm{M}=3.52)$.

An overview of the respondent students' mean scores in the whole questionnaire aspects can shed light on the relationship between these aspects and meanwhile can show the effect of one aspect on the others. For instance, perceptions about ease and barriers of use might may have an effect on the perceived usefulness. Table 5 shows the mean scores of all questionnaire aspects.

Table 5: Mean scores of students' perceptions about the whole questionnaire aspects

\begin{tabular}{|c|c|c|c|}
\hline Questionnaire aspect & M & Agreement level & Rank \\
\hline Perceived Usefulness of Smartphone Use & 3.90 & Agree & $1_{\text {st }}$ \\
\hline Perceived Ease of Smartphone Use & 3.80 & Agree & $2_{\text {nd }}$ \\
\hline Perceived Barriers for Smartphone Use & 3.77 & Agree & $3_{\text {rd }}$ \\
\hline Perceived Effects of Smartphone Use & 2.96 & Neutral & $4_{\text {th }}$ \\
\hline
\end{tabular}

Mean scores in all aspects indicate that students' perceptions toward the usefulness of smartphone use in learning are higher than their perceptions about the perceived ease, barriers, and effects of smartphone use though these perceptions are to some extent of moderate degrees. Mean scores prove that students believe in the usefulness of smartphone once it is used as a learning tool despite the fact that its ease to use, the barriers it faces and the effects that might be caused by this use of smartphone. Thus, it can be concluded that students prefer to use their smartphones in learning and the benefits they get can overcome any difficulty or hindrance they face.

\section{DISCUSSION}

Undertaking the present study was motivated by the aim of identifying the perceptions of university undergraduates toward the ease, usefulness, effects and barriers of smartphone use as a learning tool. Results indicated that students perceived the usefulness of smartphones in learning more important than other aspects. The ease of reading via smartphones was the fact, on which most of respondent students' agreed. While using smartphones to access emails and share lecture materials were the most distinguished advantages of smartphone use in learning. Moreover, the consumption of a lot of data bundle, which increases students' expenditure, was perceived as the most important effect on students' learning process. In addition, students' inability to access internet bundle or Wi-Fi connection in addition to the unstable Internet connectivity impede their abilities to online access of the course information and materials. These results are in line with the results of studies showing that perceived usefulness and perceived ease of use have a substantial effect on user intentions. Whereas, factors such as compatibility, efficiency, effectiveness and subjective satisfaction moderately and weakly affect the smartphone user intentions (Nabot, Omar, \& Almousa, 2020). They are also in agreement with the results of studies revealing that the actual use of smart phones for learning is significantly influenced by students' intention to use. Whereas, behavioural intention to use smartphones for learning is largely influenced by the users' perceived usefulness and attitude towards the smartphone (Sek, Lau, Teoh, Law, \& Parumo, 2010). They also corroborate the results of studies proving that the use of mobile devices creates significant awareness among students towards online learning (Obiefuna \& Offorma, 2014). They also emphasize the findings of studies indicating that the behavioral intention to keep using a smartphone was significantly influenced by perceived ease of use, perceived usefulness and attitude toward keeping using a smartphone (Osorio \& Risco, 2019). Besides, these findings ascertain the fact that using smartphones for the learning process is not the first priority of university undergraduates (Shishakly, 2019).

One interesting cause for these perceptions is due to the advanced capabilities and innovative features of smartphone technology that can easily engage them in learning activities (Lazim \& Sasitharan, 2014). Concerning the usefulness of using smartphones in learning, results indicated somewhat acceptable agreement on the benefits that can be obtained. This might be due to the differences between participants themselves regarding the Internet service, whether limited or unlimited. Students who have unlimited services rely heavily on the use of the smartphone while students who have a prepaid service will have a restricted use (Osorio \& Risco, 2019). In addition, 
the availability of smartphone friendly applications related to the contents of the learning can encourage more and more effective use of smartphones (Kadry\& Roufayel, 2017). The moderate level of students' agreement on the smartphone ease of use, usefulness, effects and barriers reflects the reality that each student has his own objective when accessing the learning management systems (LMSs) via their own smartphones (Shishakly, 2019). However, smartphones have proved their success in enhancing students' achievement because teachers and learners have been profiting from their integrated applications by saving time, effort and cost while communicating via various learning objects such as texts, photos, videos, graphics, and animations (Elfeky\& Elbyaly, 2016).

In conclusion, results of the present study have shown that smartphone technology is accepted in learning through many useful tools. Nevertheless, significant differences between students' perceptions towards the ease of use, usefulness, effects and barriers of smartphone use were noticed. However, the insistence of students to use these smartphones in learning was clear and evident.

\section{CONCLUSION}

Smartphones are attractive tools for the majority of young people particularly university undergraduates. They try to have the newest and most expensive models because of their numerous integrated enhancements. Smartphones' ease of use, usefulness and positive effects on learning encourage, not only students but also instructors to use them in the educational process, especially for online learning. Nevertheless, the negative effects they might have on learners and the barriers that might impede the process of learning may have significant roles in motivating learners and instructors to use them as learning tools. The present study can be viewed as an attempt to reveal some of the bad effects that smartphone use can impose on students and students' learning. Barriers impeding the effective use were also of the main concern of the present study. None ignores that facing difficulty in doing anything can change one's attitude, perception and conviction. Thus, it is important, before studying the smartphone ease of use and usefulness, to investigate what barriers can be ahead of students and what bad effects they can experience during the process of learning. Technology integration in education is something great when the barriers and bad effects are distinguished, understood and overcome.

\section{SOURCES OF FUNDING}

This research received no specific grant from any funding agency in the public, commercial, or not-for-profit sectors.

\section{CONFLICT OF INTEREST}

The author have declared that no competing interests exist.

\section{ACKNOWLEDGMENT}

None.

\section{REFERENCES}

[1] Adjei, N. D. (2019). The Use and Effect of Smartphones in Students' Learning Activities: Evident from The University of Ghana, Legon, Library Philosophy and Practice (e-journal), 1-38. https://digitalcommons.unl.edu/libphilprac/2851/

[2] Al Fawareh, H. M. \& Jusoh, S. (2017). The Use and Effects of Smartphones in Higher Education, International Journal of Interactive Mobile Technologies (iJIM), 11 (7). https://doi.org/10.3991/ijim.v11i6.7453

[3] Alzougool, B. \& Almansour, J. (2017). The Use of Smartphone for Learning Activities by University Students in Kuwait, Paper Presented in the 4th Teaching \& Education Conference, Venice. https://ideas.repec.org/p/sek/itepro/4907508.html

[4] Ary, D., Jacobs, L. C., \& Sorensen, C. (2006). Introduction to Research in Education, (8th Edition), Belmont, Canada: Wadsworth. https://www.modares.ac.ir/uploads/Agr.Oth.Lib.12.pdf 
[5] Brown, D., Ferguson, F., Grant, M., Jones, L., Sweeney, J., \& Tamim, S. (2015). Teaching and Learning with Mobile Computing Devices: Case Study in K-12 Classrooms USA. TechTrends, 59 (4), 32-45. https://link.springer.com/article/10.1007/s11528-015-0869-3

[6] Cochrane, T. D. (2010). Beyond the Yellow Brick Road: Mobile Web 2.0 Informing a New Institutional E Learning Strategy ALT-J, Research in Learning Technology, 18 (3), 221-231. DOI: $10.1080 / 09687769.2010 .529110$

[7] Cochrane, T. and Bateman, R. (2010). Smartphones Give you Wings: Pedagogical Affordance of Mobile Web 2.0, Australasian Journal of Educational Technology, 26 (1), 1-14. DOI: https://doi.org/10.14742/ajet.1098

[8] Computer Hope (2021). Accessed on 3/3/2021 https://www.computerhope.com/jargon/s/smartphone.htm

[9] Elfeky, A. I. M., \& Elbyaly, M. Y. H. (2016). The Impact of Learning Object Repository (lor) in the Development of Pattern Making Skills of Home Economics Students, British Journal of Education, 4(2), 87-99.

[10] Esmaeili, M., \& Eydgahi, A., \& Amanov, I. (2015, June), Perceptions of Students toward Utilizing Smartphones in the Classroom Paper presented at 2015 ASEE Annual Conference \& Exposition, Seattle, Washington. $10.18260 / \mathrm{p} .24561$

[11] Godwin-Jones, R. (2011). Mobile Apps for Language Learning. Language Learning \& Technology, 15 (2), 2-11. https://scholarspace.manoa.hawaii.edu/bitstream/10125/44244/15_02_emerging.pdf

[12] Iqbal, S. \& Bhatti, Z. A. (2020). A Qualitative Exploration of Teachers' Perspective on Smartphones Usage in Higher Education in Developing Countries, International Journal of Educational Technology in Higher Education, 17-29 https://doi.org/10.1186/s41239-020-00203-4

[13] Kadry, S. \& Roufayel, R. (2017). How to Use Effectively Smartphone in the Classroom, 2017 IEEE Global Engineering Education Conference (EDUCON). DOI: 10.1109/EDUCON.2017.7942884

[14] Kondo, M., Ishikawa, Y., Smith, C., Sakamoto, K., Shimomura, H., Wada, N. (2012). Mobile Assisted Language Learning in University EFL Courses in Japan: Developing Attitudes and Skills for Self-Regulated Learning. ReCALL, 24(2), 169-187. DOI: https://doi.org/10.1017/S0958344012000055

[15] Kyobe, R. \& Van Belle, J. (2018). The Impact of Smart Phones on the Students' Learning Experience in Higher Education Institutions in South Africa, Proceedings of the 6th International Conference on M4D Mobile Communication Technology for Development, 15-16 November 2018. DOI: 10.13140/RG.2.2.28042.72641

[16] Lazim, H. M. \& Sasitharan. (2014). The Smartphone Technology Acceptance among Malaysian Young Adults. In: 4th International Conference on Technology and Operations Management (ICTOM04), 18-19 August 2014, Kuala Lumpur, Malaysia. http://repo.uum.edu.my/id/eprint/15997

[17] Masadeh, T. S. Y. \& Elfeky, A. I. M. (2016). Efficacy of Open-Source Learning Management Systems in Developing the Teaching Skills of English Language Student Teachers, American Journal of Educational Research, 4 (4), 329-337. Doi: 10.12691/education-4-4-6

[18] Masadeh, T. S. Y. (2021). Prevalence of Nomophobia and Cyberloafing Behaviors among Undergraduate Students, European Journal of Education Studies, 8 (2). DOI: http://dx.doi.org/10.46827/ejes.v8i2.3580

[19] Mohammadi, M., Sarvestani, M. S. \& Nouroozi, S. (2020). Mobile Phone Use in Education and Learning by Faculty Members of Technical-Engineering Groups: Concurrent Mixed Methods Design, Frontiers in Education, 5 (16). https://doi.org/10.3389/feduc.2020.00016

[20] Nabot, A., Omar, F. \& Almousa, M. (2020). Perceptions of Smartphone Users' Acceptance and Adoption of Mobile Commerce (MC): The Case of Jordan, Journal of Computer Science, 16 (4), 532.542. DOI: 10.3844/jcssp.2020.532.542

[21] Naz, S., Rasheed, M., \& Rasheed, T. (2019). The Role of Smartphones in Learning English: A Study of Learners' Perspectives, paper presented at International Conference on Research in Humanities, 7-9 march, 2019 London, United Kingdom. https://www.dpublication.com/wp-content/uploads/2019/03/ICRH-1232.pdf232.pdf

[22] Nikolopoulou, K. (2019). Secondary Education Teachers' Perceptions of Mobile Phone and Tablet use in Classrooms: Benefits, Constraints and Concerns, J. Comput. Educ, 7(2):257-275. https://link.springer.com/article/10.1007/s40692-020-00156-7

[23] Osorio, M. R. \& Risco, A. A. (2019). Intention to Use Smartphones among Peruvian University Students, International Journal of Interactive Mobile Technologies (iJIM), $13 \quad$ (3). https://doi.org/10.3991/ijim.v13i03.9356

[24] PC Magazine Encyclopedia. https://www.pcmag.com/encyclopedia/term/smartphone (2021)
tphone Accessed on 3/3/2021. International Journal of Research -GRANTHAALAYAH 
[25] Real, F. J., DeBlasio, D., Rounce, C., Henize, A. W., Beck, A. F., \& Klein, M. D. (2018). Opportunities for and Barriers to Using Smartphones for Health Education among Families at an Urban Primary Care Clinic. Clinical Pediatrics, 57 (11), 1281-1285. https://doi.org/10.1177/0009922818772157

[26] Rung, A., Warnke, F., \& Mattheos, N. (2014). Investigating the Use of Smartphones for Learning Purposes by Australian Dental Students, JMIR mHealth uHealth, 2(2), doi:10.2196/mhealth.3120

[27] Sek, Y. W., Lau, S. H., Teoh, K. K., Check-Yee Law, C. Y., \& Parumo, S. (2010). Prediction of User Acceptance and Adoption of Smart Phone for Learning with Technology Acceptance Model. Journal of Applied Sciences, 10: 2395-2402. DOI: 10.3923/jas.2010.2395.2402

[28] Shishakly, R. (2019). Smartphones Enhance the Management of Learning Processes in Higher Education: A Case Study in Ajman University, United Arab Emirates, International Conference Proceeding Series (ICPS) IC4E '19: Proceedings of the 10th International Conference on E-Education, E-Business, E-Management and E-Learning. DOI: https://doi.org/10.1145/3306500.3306513

[29] White, J. \& Mills, D. (2014). Examining Attitudes towards and Usage of Smartphone Technology among Japanese University Students Studying EFL, CALL-EJ, 15(2), 1-15. http://callej.org/journal/152/White_Mills_2014.pdf

[30] Wisnuwardana, I. (2019). Students' Attitudes towards the Use of Smartphone for Language Learning Purposes, Journal of English Teaching Adi Buana, 4 (2), 178- 191. https://core.ac.uk/download/pdf/333841903.pdf

[31] Yeik, K. K. (2018). Assessing Cyberloafing Behaviour among University Students: A Validation of the Cyberloafing Scale, Pertanika Journal of Social Science and Humanities 26 (1). http://www.myjurnal.my/filebank/published_article/81107/24.pdf 